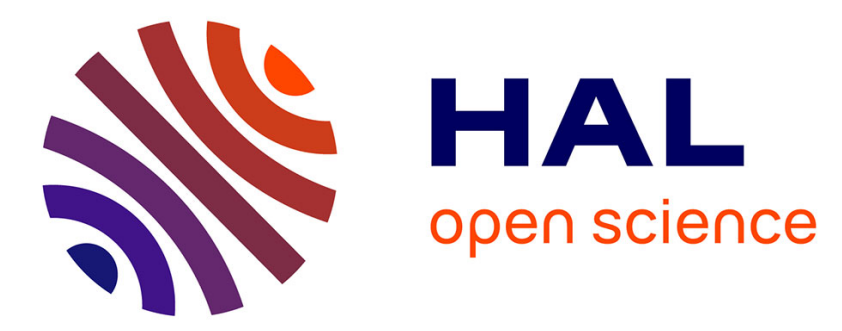

\title{
Studies on apple protopectin: I. Extraction of insoluble pectin by chemical means
}

Catherine M.G.C. Renard, A.G.J. Voragen, J.F. Thibault, W. Pilnik

\section{To cite this version:}

Catherine M.G.C. Renard, A.G.J. Voragen, J.F. Thibault, W. Pilnik. Studies on apple protopectin: I. Extraction of insoluble pectin by chemical means. Carbohydrate Polymers, 1990, 12 (1), pp.9-25. hal-02711055

\section{HAL Id: hal-02711055 \\ https://hal.inrae.fr/hal-02711055}

Submitted on 1 Jun 2020

HAL is a multi-disciplinary open access archive for the deposit and dissemination of scientific research documents, whether they are published or not. The documents may come from teaching and research institutions in France or abroad, or from public or private research centers.
L'archive ouverte pluridisciplinaire HAL, est destinée au dépôt et à la diffusion de documents scientifiques de niveau recherche, publiés ou non, émanant des établissements d'enseignement et de recherche français ou étrangers, des laboratoires publics ou privés. 


\title{
Studies on Apple Protopectin: I. Extraction of Insoluble Pectin by Chemical Means
}

\author{
C. M. G. C. Renard ${ }^{a}$, A. G. J. Voragen ${ }^{b}$, J. F. Thibault ${ }^{a} \&$ W. Pilnik ${ }^{b}$ \\ "Institut National de la Recherche Agronomique, Laboratoire de Biochimie et \\ Technologie des Glucides, rue de la Géraudière, 44072 Nantes, France \\ ${ }^{b}$ Agricultural University, Department of Food Science, Bomenweg 2, 6703 HD \\ Wageningen, The Netherlands
}

(Received 2 October 1988; revised version received 12 December 1988; accepted 20 December 1988)

\begin{abstract}
The pectic material from Golden Delicious apples, strongly bound in the cell walls of parenchymatous tissues (not extractible with CyclohexaneDiamino-Tetracetic Acid (CyDTA)) was extracted by: (i) successively, hot buffer, hot acid and cold sodium hydroxide, (ii) sodium carbonate $\left(4^{\circ} \mathrm{C}\right.$ then $20^{\circ} \mathrm{C}$ ) and (iii) chlorite. The pectin extracts were analysed for uronide, neutral sugars and protein contents, and degrees of methylation and acetylation. They were also subjected to gel-filtration and ionexchange chromatography. Subfractions obtained by ion-exchange were also analysed.

Approximately $55 \%$ of the pectic material was not extracted by the CyDTA. Hot buffer, hot acid and chlorite extracted small amounts of relatively highly methoxylated and acetylated pectins. The most efficient extractants were the cold carbonate and the cold sodium hydroxide. They extracted saponified pectins that exhibited similar behaviour on gel-filtration and ion-exchange chromatography, showing two subfractions, of which one was rich in neutral sugars and had a high molecular weight. There was no evidence of phenolic interlinkages.
\end{abstract}

\section{INTRODUCTION}

Much of the research done on apple pectins has been concerned with their extraction, structure and changes during ripening (Barrett \& Northcote, 1965; Knee, 1973a, b; Knee et al., 1975; Knee, 1978a, b; De Vries et al., 1981, 1982, 1983a,b, 1984; De Vries, 1983; Aspinall \& Fanous, 1984; Stevens \& Selvendran, 1984). Most of the investigations

Carbohydrate Polymers 0144-8617/89/\$03.50 - (C) 1989 Elsevier Science Publishers Ltd, England. Printed in Great Britain 
focused on the pectin that could readily be extracted from apple cell walls using non-degradative techniques (cold or hot water or buffers, chelating agents). The structure of the soluble pectin has been studied in detail by De Vries (1983). He proposed a model of the pectin molecules, in which neutral sugars side chains are arranged in blocks (hairy regions) separated by unsubstituted regions containing almost exclusively galacturonic acid residues (smooth regions). With regard to apple pectin he established that the degree of methylation approaches $100 \%$ in the hairy regions and $70 \%$ in the smooth regions, and that in these smooth regions the methoxyl groups are not distributed in blocks. However the methods he used extracted less than $50 \%$ of the total pectin from the cell walls, and little is known about the residual pectic material.

The aim of this work was to study and characterize this residual pectic material, which is often called protopectin (Kertesz, 1951; Pilnik \& Voragen, 1970), as near as possible to its native state. Two approaches can be used: chemical extraction using well known degradative procedure, and enzymatic extraction using highly purified enzymes. The results of degradative chemical extraction techniques are reported here. These results provide some information on the structure of the protopectin and it is hoped that they will provide a background for interpretation of the results of enzymatic extractions.

\section{MATERIALS AND METHODS}

\subsection{Plant material}

Apples (Malus malus L., Rosaceae, var. Golden Delicious) were obtained from the Sprenger Institute (Wageningen, The Netherlands). They were harvested in 1986 and had been stored in controlled atmosphere until mid-December. They were then removed and put at ambient conditions until mid-January.

\subsection{Chemicals}

CyDTA (titriplex IV) was purchased from Merck (Darmstadt, BRD) as a free acid and converted to the disodium salt prior to use. Sodium chlorite (technical grade) was obtained from BDH (Poole, UK). All other chemicals were of analytical grade.

\subsection{Extractions}

Preparation of Alcohol Insoluble Solids (AIS): peeled and cored apples were ground in a Braun kitchen grinder. The pulp was immersed in boil- 
ing $96 \%$ ethanol (2 litres of ethanol per kilogram of pulp), boiled for 20 min and collected on a Büchner. The material was resuspended in $70 \%$ ethanol and extracted at room temperature until the filtrate was sugarfree (the sugars were detected in the filtrate by the phenol-sulfuric acid test). The pulp was then pressed in a cheese cloth and an aliquot was dried by solvent exchange (acetone) prior to analysis.

Preparation of partially depectinated cell wall material (CyDTA-IR): pressed AIS was suspended in a solution of CyDTA $\mathrm{Na}_{2}, 0.02 \mathrm{M} \mathrm{pH}$ 4.8-5 at room temperature and stirred mechanically for $6 \mathrm{~h}$. After centrifugation $(27300 \mathrm{~g}, 20 \mathrm{~min})$ the pellets were resuspended in fresh CyDTA solution and left overnight at $4^{\circ} \mathrm{C}$. The extraction was repeated until the supernatant was sugar-free (6 extractions). The residual pulp (CyDTA Insoluble Residue CyDTA-IR) was washed with distilled water, freeze-dried and ground in a Cullati hammer mill. The first two extracts (fraction CyDTA Soluble Pectin CySP) were pooled, dialysed against distilled water for $96 \mathrm{~h}$ (changed every $12 \mathrm{~h}$ ), concentrated and stored as described for the other fractions.

Extraction of pectins from CyDTA-IR: the extraction scheme is given in Fig. 1. Hot buffer, hot $\mathrm{HCl}$ and cold $\mathrm{NaOH}$ extractions were carried out according to DeVries et al. (1981) and Rombouts and Thibault (1986). A temperature of $60^{\circ} \mathrm{C}$ was used for the hot extraction steps. CyDTA-IR $(5 \mathrm{~g})$ was first treated three times with $200 \mathrm{ml}$ of $0.05 \mathrm{M}$ sodium succinate/succinic acid buffer $(\mathrm{pH} 4.5)$ at $60^{\circ} \mathrm{C}$ for $30 \mathrm{~min}$. The slurry was centrifuged $(27300 \mathrm{~g}, 20 \mathrm{~min}$ ), giving the Succinate Soluble Pectin fraction (SSP). Succinic acid/sodium succinate buffer was preferred to acetic acid/sodium acetate buffer in order to avoid interference with measurement of the degree of acetylation. This extraction was followed by an extraction with hot dilute hydrochloric acid $(0.05 \mathrm{M}$, $60^{\circ} \mathrm{C}$, pH 1.3) also three times with $200 \mathrm{ml}$ for $30 \mathrm{~min}$. After centrifugation $(27300 \mathrm{~g}, 20 \mathrm{~min})$ the supernatant containing the $\mathrm{HCl}$ Soluble Pectin (HSP) was neutralized to $\mathrm{pH} 4.5$ using $1 \mathrm{~m} \mathrm{NaOH}$. The residual material was further treated with $\mathrm{NaOH} 0.05 \mathrm{M}+$ EDTA $5 \mathrm{~mm} \mathrm{pH} 12 \cdot 5$ ) at $4^{\circ} \mathrm{C}$, three times with $200 \mathrm{ml}$ for $30 \mathrm{~min}$. After centrifugation $(27300 \mathrm{~g}, 20 \mathrm{~min})$ the slurry gave the $\mathrm{NaOH}$ Soluble Pectin (OHSP), neutralized to $\mathrm{pH} 4.5$ by $1 \mathrm{M} \mathrm{HCl}$ and the $\mathrm{NaOH}$ Insoluble Residue (OHIR).

Sodium carbonate extractions were carried out according to Selvendran et al. (1985): the CyDTA-IR (5 g) was suspended in $500 \mathrm{ml} 0.05 \mathrm{M}$ $\mathrm{Na}_{2} \mathrm{CO}_{3}$ (pH 10.3) containing $20 \mathrm{~mm} \mathrm{NaBH}_{4}$ to prevent oxidative degradation of polysaccharide chains, and stirred overnight at $4^{\circ} \mathrm{C}$. After centrifugation $(27300 \mathrm{~g}, 20 \mathrm{~min}$ ), the supernatant solution (containing Cold Carbonate Soluble pectin CCSP) was neutralized to $\mathrm{pH} 4.5$ by $1 \mathrm{M}$ $\mathrm{HCl}$. The pellet was further extracted with $500 \mathrm{ml}$ of the same sodium 


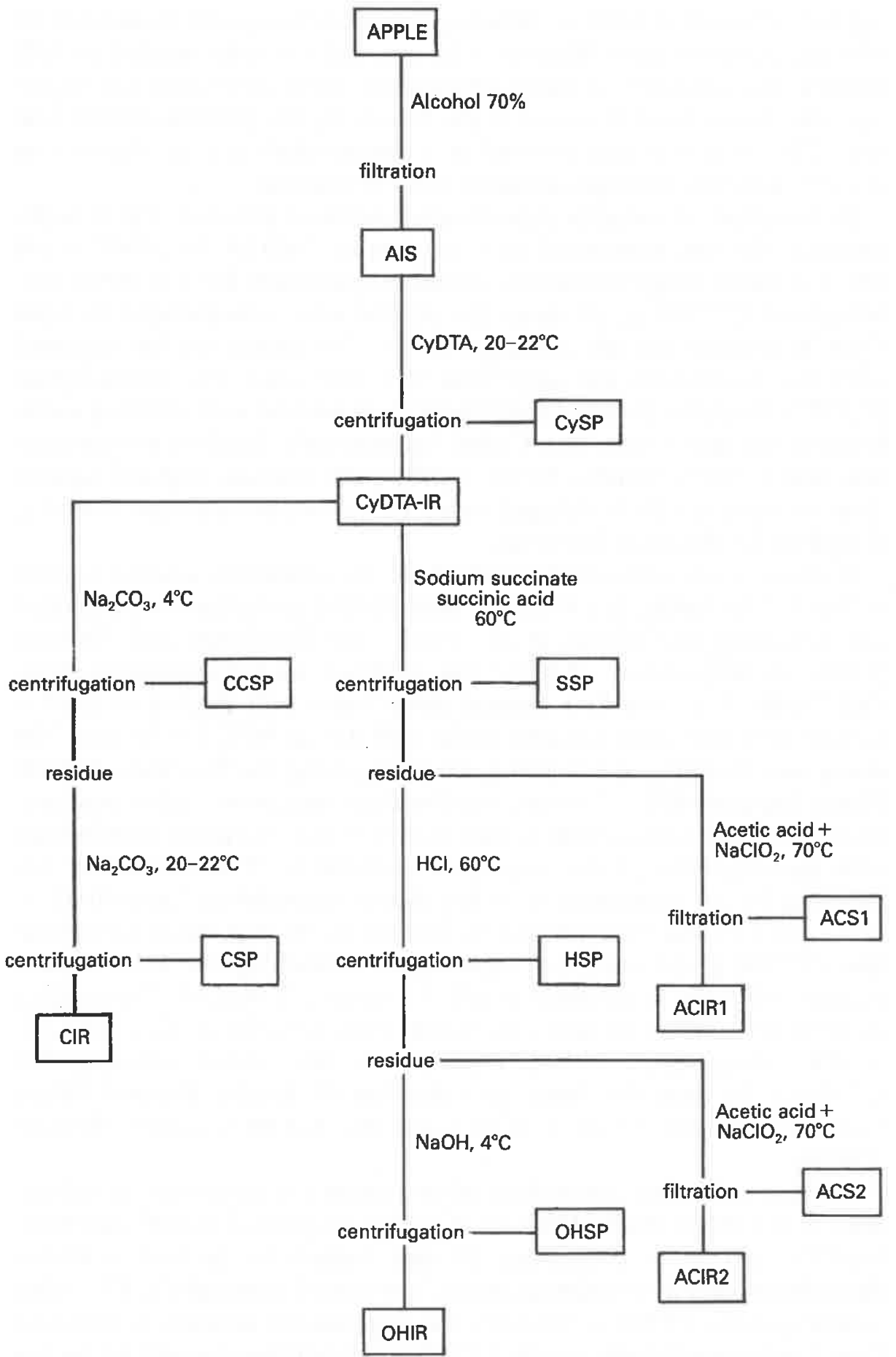

Fig. 1. Scheme for extraction of pectin fractions from apple cell wall material. 
carbonate solution for $3 \mathrm{~h}$ at room temperature, resulting in the Carbonate Soluble pectin (CSP) and the Carbonate Insoluble residue (CIR).

Acetic acid/sodium chlorite $\left(\mathrm{NaClO}_{2}\right)$ extractions were performed following the procedure of Selvendran et al. (1975). The residues $(5 \mathrm{~g})$ were suspended in distilled water in a loosely stoppered flask and heated to $70^{\circ} \mathrm{C}$. Acetic acid $(0.12 \% \mathrm{v} / \mathrm{v})$ and sodium chlorite $\left(\mathrm{NaClO}_{2}, 0.3 \%\right.$ $\mathrm{w} / \mathrm{v}$ ) were added and the contents were stirred for $15 \mathrm{~min}$, after which the same extractants were added once again and the contents were stirred for another $15 \mathrm{~min}$. In order to prevent a build-up of chlorine dioxide in the head-space, the flask was continually flushed with nitrogen. After cooling, the contents were filtered on G3 sintered glass and the residue was washed with 1 litre of distilled water. The filtrate was purged with nitrogen to remove the dissolved gases prior to being neutralized to $\mathrm{pH}$ 4.5. This procedure allowed the extraction of the Acetic acid/Chlorite Soluble fraction 1 (ACS1) from the residue of the hot succinate extraction, leaving the Acetic acid/Chlorite Insoluble Residue 1 (ACIR1). From the residue of the hot acid extraction the Acetic acid/Chlorite Soluble fraction 2 (ACS2) was obtained, leaving the Acetic acid/Chlorite Insoluble Residue 2 (ACIR2).

All the fractions were dialysed, freeze-dried and redissolved in distilled water. These fractions were used for analyses. For chromatography and long range storage low molecular weight components were eliminated by ultrafiltration in an Amicon cell using a Diaflo PM10 membrane (theoretical cutoff: 10000 Daltons). The concentrated extracts are kept at $-18^{\circ} \mathrm{C}$. Aliquots were thawed or freeze-dried according to needs.

The residues were washed with distilled water and freeze-dried.

\subsection{Chromatography}

Ion-exchange chromatography: $5-10 \mathrm{mg}$ (in $1 \mathrm{ml}$ ) of the pectin fractions were applied to a $10.5 \times 1.3 \mathrm{~cm}$ column of DEAE Sepharose CL-6B (Pharmacia) equilibrated with $0.005 \mathrm{M}$ succinic acid/sodium succinate buffer at $\mathrm{pH} 4 \cdot 8$. After loading, the column was washed with $0.005 \mathrm{M}$ buffer $(60 \mathrm{ml})$ and eluted with a linear gradient from $0.005 \mathrm{M}$ to $0.4 \mathrm{M}$. Elution was continued with $30 \mathrm{ml}$ of $0.4 \mathrm{M}$ buffer and $30 \mathrm{ml}$ of $1 \mathrm{M}$ buffer. Experiments were carried out at room temperature. Fractions of $2 \mathrm{ml}$ were collected and assayed for uronic acids and neutral sugars content. Appropriate fractions were pooled, dialysed and freeze-dried for quantification of individual sugars.

Gel-filtration chromatography: $2-5 \mathrm{mg}$ (in $0.5 \mathrm{ml}$ ) of the concentrated extracts were applied to an $85 \times 1.3 \mathrm{~cm}$ column of Sephacryl S500 
(Pharmacia) eluted with Tris/succinate buffer $0.1 \mathrm{~m} \mathrm{pH} 6$ at a flow rate of $8 \mathrm{ml} / \mathrm{h}$. Fractions of $2 \mathrm{ml}$ were collected and assayed for uronic acids and neutral sugars content. The excluded (Vo) and included $(\mathrm{Vt})$ volumes were determined with amylopectin (AVEBE, Veendam, The Netherlands) and glucose respectively. In order to estimate the molecular weights of the pectins in the fractions, pectins of viscosity average molecular weights from 10000 to 100000 prepared by ball-milling according to van Deventer-Schriemer and Pilnik (1987) were injected. Since the highest molecular weight pectin available $(100000)$ eluted at $K_{\mathrm{av}}=0 \cdot 6$, a complete calibration curve was not determined in this experiment.

\subsection{Analytical}

The uronide content was measured by the metahydroxydiphenyl (mHDP) method as anhydrogalacturonic acid (Blumenkrantz \& AsboeHansen, 1973; Ahmed \& Labavitch, 1977). Total sugars were determined as anhydroglucose by the phenol-sulphuric assay (Dubois et al., 1956). In the chromatography fractions uronic acid and total sugars were estimated by respectively automated $\mathrm{mHDP}$ and orcinol assays (Thibault, 1979; Tollier \& Robin, 1979). In this automated method correction was made for the interference of the uronic acid in the orcinol assay to calculate neutral sugars contents (expressed as anhydroglucose).

Individual neutral sugars were analysed as their alditol acetates derivatives by gas chromatography. Derivatization was carried out according to Hoebler et al. (1989). Cellulose was determined according to Updegraff (1969).

Protein was measured in the insoluble residues by semi-automatic micro-Kjeldahl (Roozen \& Ouwehand, 1978) using a coefficient of $6 \cdot 25$, in the extracts by an automated Biuret method, and was detected in some chromatography fractions by the absorbance at $280 \mathrm{~nm}$.

The degrees of esterification with methyl and acetyl of the pectins were estimated by HPLC according to Voragen et al. (1986).

Phenolic acids were detected and identified as described by Rombouts and Thibault (1986).

\section{RESULTS}

\subsection{Composition of the extracts}

Table 1 shows the composition of materials, percent yields and composition of fractions and residues. 


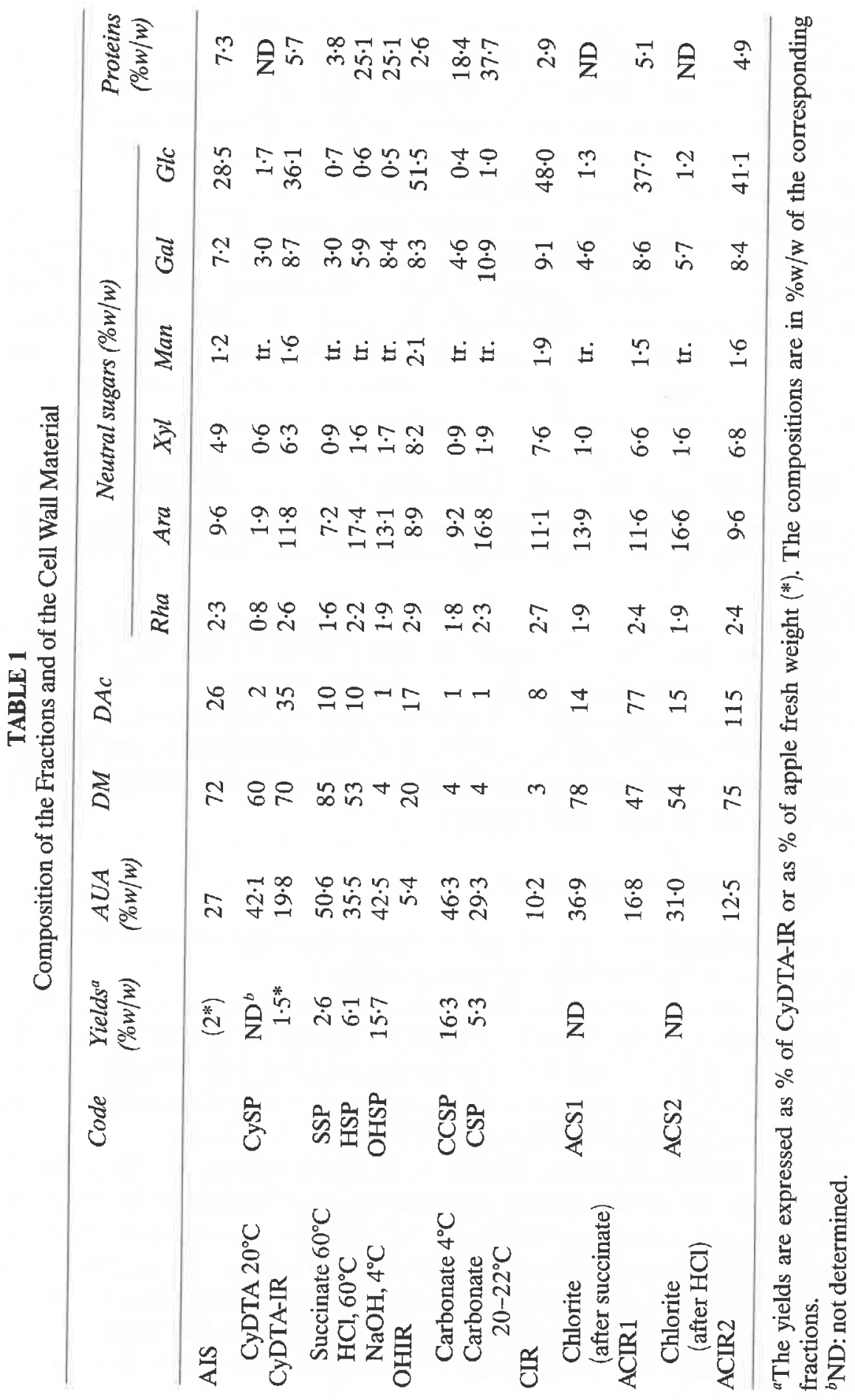


CyDTA extracted approximately $45 \%$ of the galacturonic acid residues present in the AIS. The alkaline conditions (OHSP and CCSP) gave respectively 34 and $38 \%$ of the uronides from CyDTA-IR. Twenty to thirty percent of the pectin still remained in the residues OHIR and CIR. The alkalis also extracted substantial quantities of proteins. The acetic acid/sodium chlorite treatments gave very low yields.

Galacturonic acid was the main component of all the extracts obtained except CSP, which was very rich in proteins. The neutral sugar content of the extracts varied between treatments. However, their relative distribution was similar; arabinose was the main neutral sugar, representing generally more than half of the neutral sugars. The extracts also contained galactose, rhamnose, xylose, low glucose contents and traces of mannose. CySP had a different composition, with molar percentages of 33, 24 and 21 respectively for arabinose, glucose and galactose. HSP and the acetic acid/sodium chlorite extracts ACS1 and ACS2, which were also subjected to a low $\mathrm{pH}$ during extraction, had the highest neutral sugars and arabinose contents (more than $60 \mathrm{~mol} \%$ of the neutral sugars).

The pectin extracted with CyDTA had a high methylation degree, though lower than SSP. The alkali extracts OHSP, CCSP and CSP were deesterified during extraction. The acetyl contents of SSP, HSP, ACS1 and ACS2 were high. It is believed that the high content of acetic acid in ACIR1 and ACIR2 was due to the extraction procedure. Though saponification accompanies the alkaline treatments, the residues OHIR and CIR retained some acetyl groups.

\subsection{Ion-exchange fractionation}

The ion-exchange patterns of the pectin extracts and the neutral sugars composition of subfractions are shown in Fig. 2.

The recoveries of ion-exchange fractionations were around $100 \%$ except for the alkaline extracts (OHSP, CCSP and CSP) with recoveries respectively of 24,27 and $51 \%$ for uronic acid, but 108,98 and $89 \%$ for neutral sugars. This indicates the presence of a galacturonan mostly devoid of neutral sugars, which was retained on the column.

Neutral polysaccharides, which were not retained on the column, were present in all the pectin extracts: no purification of acidic polysaccharides, by copper precipitation for example, has been carried out. These neutral components were particularly important in HSP. The pectic materials were eluted during the buffer gradient. The $1 \mathrm{M}$ buffer eluted traces or almost no additional material from the column. $0 \cdot 3 \mathrm{M}$ sodium hydroxide also failed to elute additional acidic polysaccharides. 

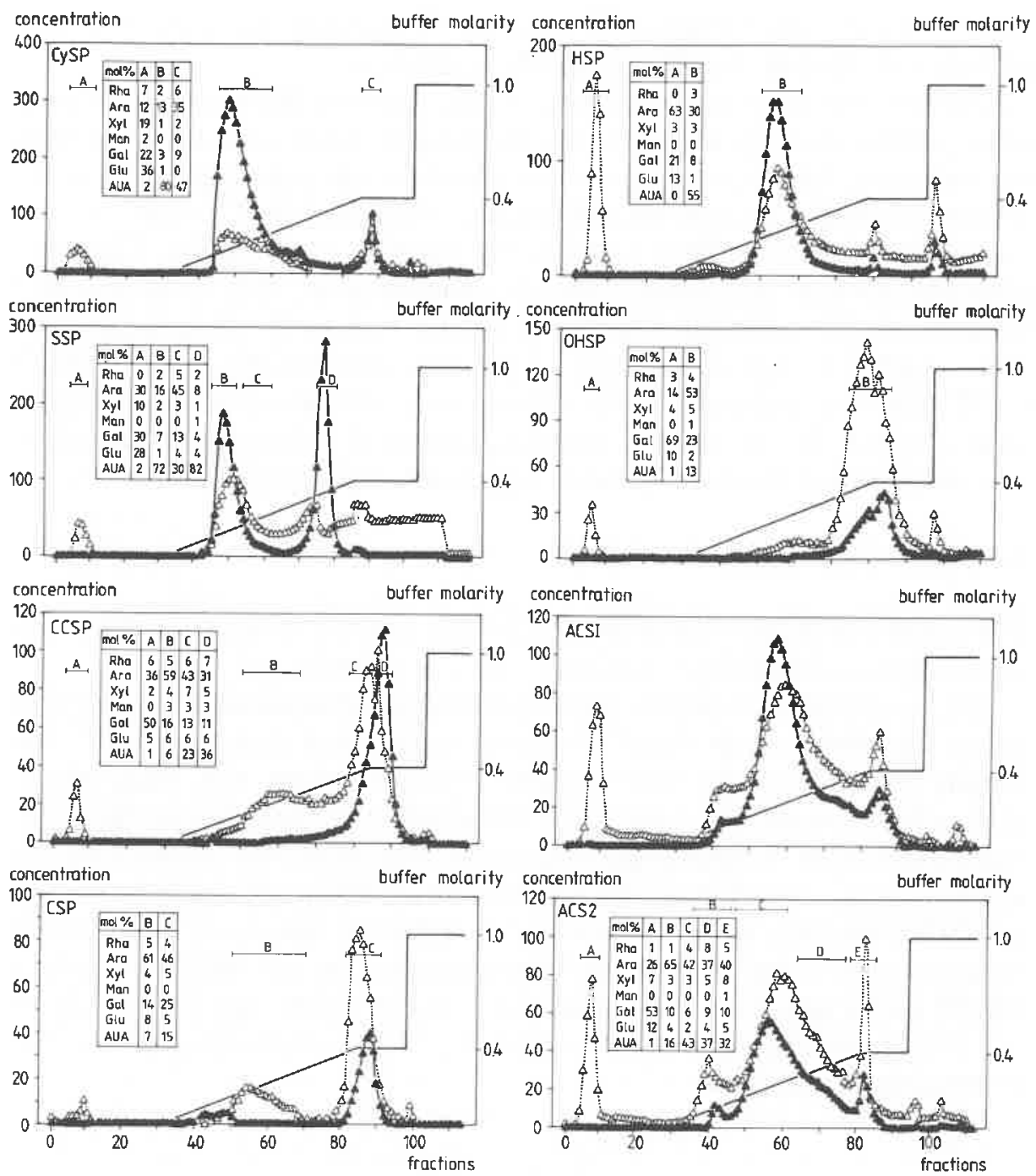

Fig. 2. Elution of the pectin extracts from apple AIS on DEAE Sepharose CL-6B with succinic acid/sodium succinate buffer $(\mathrm{pH}=4 \cdot 8$ ) (see Fig. 1): $-\mathbf{\Delta}$, anhydrogalacturonic acid $(\mu \mathrm{g} / \mathrm{ml}) ; \cdots \Delta \cdots$, neutral sugars $(\mu \mathrm{g} / \mathrm{ml}) ;-$ succinate $\mathrm{Na} /$ succinic acid $(\mathrm{mol} / \mathrm{l})$.

All the pectic extracts eluted at ionic strengths consistent with their degrees of methylation, except SSP, which showed two peaks, one of them eluting at high ionic strength. The pectins of CySP, HSP and OHSP appeared very homogeneous. CCSP and CSP showed two components, a minor one with a very low uronic acid content, and a major one eluting 
with $0 \cdot 4 \mathrm{M}$ succinate buffer. ACS1 and ACS2 had patterns with very wide tailing peaks that spread along the whole gradient.

The neutral sugar compositions of the retained fractions were even more similar than those of the crude extracts. Arabinose was the main neutral sugar, representing $40-76 \mathrm{~mol} \%$ of the neutral sugars. The other sugars also had a limited variation range: rhamnose 6-14 mol\%, xylose 6-8 $\mathrm{mol} \%$, galactose $16-27 \mathrm{~mol} \%$ and glucose $5-12 \mathrm{~mol} \%$. The nonretained fractions had more variable compositions: they were arabinogalactans in HSP, OHSP, CCSP and ACS2, with only minor amount of other sugars. A high proportion of glucose was present in SSP, and in CySP glucose, galactose and xylose were the predominant sugars. Unfortunately due to the very low yields of purified fractions, a complete determination of the less abundant sugars was not always possible.

\subsection{Molecular weight distribution}

The gel filtration patterns of the pectins are shown in Fig. 3. In all experiments, recoveries of approximately $100 \%$ were obtained.

All the extracts showed a wide distribution of molecular weight. Due to the ultrafiltration purification and concentration step, low molecular weight polysaccharides were absent. Neutral sugars and galacturonic acid residues were not distributed similarly in the polysaccharide containing fractions. Polysaccharide fractions that were not retained on the ion-exchange column might be responsible for this phenomenon in CySP and HSP, but they were not present in sufficient quantities in the other extracts to account for all the discrepancies. In the alkaline extracts OHSP, CCSP and CSP, two peaks were clearly visible, one peak at $K_{\mathrm{av}}$ 0.2 , rich in neutral sugars, and one at $K_{\text {av }} \sim 0.7$ composed almost exclusively of uronic acids.

\section{DISCUSSION}

\subsection{Preparation of depectinated cell wall material}

To study the non-soluble pectin, the first step is to prepare cell wall material from which the soluble pectin has been removed. This was achieved in two stages: (i) preparation of Alcohol Insoluble Solids and (ii) extensive treatment of AIS with a chelating agent, CyDTA.

Preparation of AIS is commonly used for isolation of cell wall material (Selvendran et al., 1985). Though this method has some drawbacks it is considered suitable for fruits and vegetables that are low in starch, intra- 

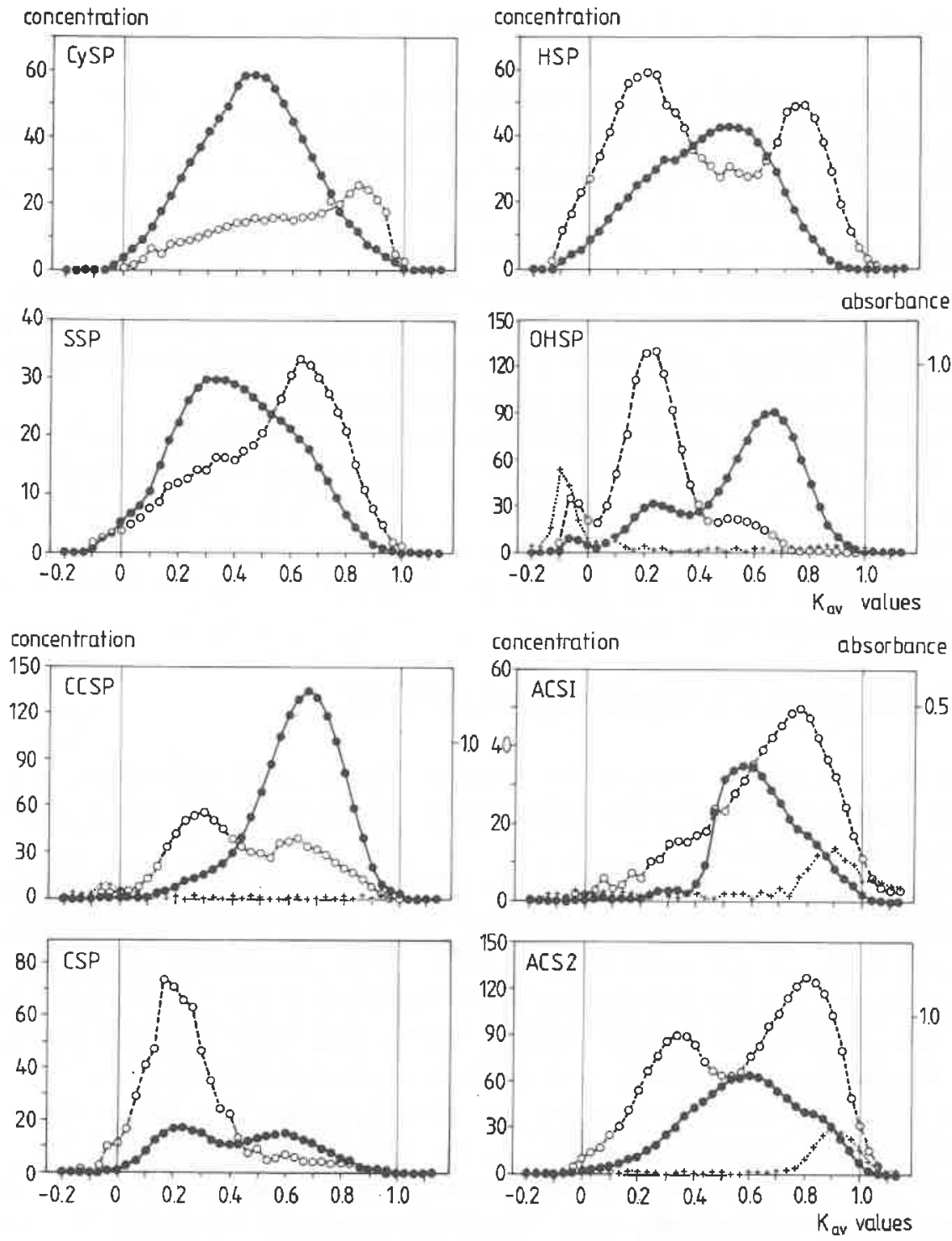

Fig. 3. Elution of the pectin extracts from apple AIS on Sephacryl S500 with Tris/ succinate buffer $(0.1 \mathrm{M}, \mathrm{pH}=6)$ (see Fig. 1): - - , anhydrogalacturonic acid; --0--, neutral sugars; $\cdots+\cdots$, proteins (absorbance at $280 \mathrm{~nm}$ ).

cellular proteins and polyphenols (Selvendran et al., 1985; Selvendran \& O'Neill, 1987). The presence of a high proportion of proteins in the AIS (7\%), compared to the $1 \%$ obtained by Stevens and Selvendran (1984) using inorganic solvents, nonetheless points out to the existence of some coprecipitation. Formation and strengthening of hydrogen bonds was 
avoided as much as possible by using $70 \%$ ethanol and not drying the AIS.

The use of CyDTA, as proposed by Jarvis et al. (1981), allows extraction of pectins at room temperature with substantially higher yields than with hot EDTA or hot ammonium oxalate (Jarvis et al., 1981; Selvendran, 1985). Jarvis (1982) extracted $31 \%, 38 \%, 37 \%$ and $26 \%$ of the pectin present in cell wall preparations of celery, cucumber, cress and tomato, respectively. Redgwell and Selvendran (1986) extracted $34 \%$ of the pectin present in the cell wall material of onions. CyDTA is mostly used at $\mathrm{pH} 6.5$ but a $\mathrm{pH}$ of $4.8-5$ was chosen to prevent transelimination of the pectin during the lengthy extraction procedure.

Selvendran et al. (1985) extracted comparable amounts of pectin from apple cell walls with CyDTA as with hot water and oxalate together. De Vries et al. (1981) extracted a total amount of $28 \%$ (unripe apples) and $33 \%$ (ripe apples) of the pectin present in apple AIS after cold water, hot water oxalate treatments, compared to the $45 \%$ obtained here from similar material with CyDTA.

\subsection{Extraction of pectins from the CyDTA-IR}

Further extractions were carried out on the partially depectinated cell wall material (CyDTA-IR) following the most common schemes proposed in the literature.

Jarvis (1982), Selvendran et al. (1985) and Selvendran and O'Neill (1987) recommend extraction by CyDTA at room temperature followed by $\mathrm{Na}_{2} \mathrm{CO}_{3}$ at $1{ }^{\circ} \mathrm{C}$ and then at $20^{\circ} \mathrm{C}$. This procedure involves two mechanisms for extraction of pectins: chelation of $\mathrm{Ca}^{2+}$ and destruction of the alkali-labile linkages (esters, some glycosidic linkages between methoxylated galacturonic acid residues, hydrogen bonds), but preserves the glycosidic linkages between the neutral sugars. The yields obtained with $\mathrm{Na}_{2} \mathrm{CO}_{3}$ were high: $16.3 \%$ of the CyDTA-IR at $4^{\circ} \mathrm{C}$ and $5.3 \%$ at $20^{\circ} \mathrm{C}(12.1 \%$ and $4.0 \%$ of the AIS $)$, slightly higher than the yields obtained by Selvendran et al. (1985) (respectively 5.4 and $2.7 \%$ of the purified cell wall).

Other authors (Souty et al., 1981; De Vries et al., 1981; Barbier \& Thibault, 1982; Rombouts \& Thibault, 1986; Saulnier \& Thibault, 1987; Massiot et al. 1988) have used chelating agents followed by hot dilute acid $\left(0.05 \mathrm{M} \mathrm{HCl}, 70\right.$ to $\left.85^{\circ} \mathrm{C}\right)$ and cold dilute alkali $(0.05 \mathrm{M} \mathrm{NaOH}$, $4^{\circ} \mathrm{C}$ ). In such a procedure an additional extraction mechanism is present: the treatment by $\mathrm{HCl}$ is a mild acid hydrolysis, to which glycosidic linkages involving arabinofuranosidic residues are particularly sensitive. As solubilisation of some pectic material by mere incubation with buffer 
was observed, a treatment by succinic acid/sodium succinate buffer was carried out prior to the $\mathrm{HCl}$ treatment. Such a solubilisation was probably due to mechanical effects of freeze-drying and grinding of CyDTA-IR. The acid extraction yields amounts of pectin $(11 \%$ of the pectin of CyDTA-IR) comparable to those obtained by De Vries et al. (1981) $(7 \%$ and $14 \%$ of the AIS pectin respectively in unripe and ripe apples). This is much lower than values reported for sugar-beet pulp (Rombouts \& Thibault, 1986), grape berries (Saulnier \& Thibault, 1987) or apricots (Souty et al., 1981; Siliha, 1985), for which the acid soluble pectin is the main fraction. The alkaline extraction proves to be the most efficient in this procedure, extracting almost as much pectin as the cold carbonate $(34 \%$ against $38 \%$ ), in spite of the previous treatments.

The acetic acid/sodium chlorite treatment, adapted from a delignification procedure, is often used to extract glycoproteins. The method brings about oxidative cleavage of the polyphenols and is thought to act by destruction of phenolic cross-links. These treatments extracted extremely low amounts of pectin from the apple CyDTA-IR, which is in agreement with the fact that the concentration of phenolic acids is very low and no ferulic acid or p-coumaric acid could be detected (results not shown): no evidence was found for the existence of phenolic interlinkages in this material.

\subsection{Composition of the starting material and of the fractions}

The apple AIS shows a composition close to those reported for apple cell wall material (Knee, 1978b; Voragen et al., 1980, 1983; Aspinall \& Fanous, 1984; Stevens \& Selvendran, 1984) but it has a lower arabinose content. The glucose present in the AIS is almost exclusively from cellulosic origin (the AIS contains $27 \%$ cellulose, as measured by the Updegraff method). The apples used for this study had been stored for four months in a controlled atmosphere and the starch initially present in these apples has been metabolized (Gorin et al., 1978). In the CyDTA-IR there has been a sharp decrease in uronic acid, and in consequence an increase of all the other sugars. However, the relative proportions of the neutral sugars were not affected $(4 / 20 / 11 / 2 / 12 / 51$ in CyDTA-IR versus $5 / 20 / 11 / 2 / 12 / 50$ in AIS for deoxysugars, arabinose, xylose, mannose, galactose and glucose respectively).

The composition of the fractions is close to that reported for apple from similar extraction procedures (Selvendran et al., 1985). The neutral sugar/uronic acid ratio varies from 0.19 in CySP to 1.3 in CSP. The relative proportions of the neutral sugars are rather stable, even though these proportions were not here as constant as has been reported ( De 
Vries et al., 1981). This is probably due to the fact that the greater diversity of the extraction methods leads to extraction of less homogeneous pectic material. The fractions that have been extracted under acidic conditions (HSP, ACS1 and ACS2) have the highest proportions of arabinose. However OHSP and CSP also have high neutral sugars/ uronic acid ratios together with higher proportions of galactose. In contrast to the results of De Vries et al. (1981) who found that the galactose/arabinose ratio decreases when the neutral sugars/uronic acids ratio increases, no relation between the galactose/arabinose ratio and the neutral sugar content was observed in this experiment. The extracted fractions all contained very low levels of mannose. This sugar has been detected in apple pectin extracts by Stevens and Selvendran (1984), Selvendran et al. (1985), Voragen et al. (1983) and Aspinall and Fanous (1984), but not by De Vries et al. (1981), Knee (1973a) and Rouau and Thibault (1984).

The fractions extracted with alkalis (OHSP, CCSP and CSP) show a high protein content $(37.7 \%$ in CSP), but the bulk of these proteins probably arises from coprecipitated intracellular material. This is further supported by their behavior in gel-filtration chromatography.

The degrees of methylation are generally in accordance with values reported by De Vries et al. (1981) and Knee $(1978 a, b)$. The degree of methylation of CySP is high. This is often the case for pectins extracted by chelating agents from cell walls of fruits: apples (De Vries et al., 1981), grape berries (Saulnier \& Thibault, 1987), apricots (Souty et al., 1981), and cherries (Barbier \& Thibault, 1982) or sugar-beet (Rombouts \& Thibault, 1986) and carrots (Massiot et al., 1988). SSP had a very high degree of methylation. Though commercial apple pectins are poor in acetyl groups, a considerable quantity of acetyl groups were present in the apple cell wall (AIS and CyDTA-IR), and some pectin fractions (SSP, HSP, ACS1 and ACS2). All the acetyl residues were assigned to the galacturonic acid residues, though other sites of attachment are known to exist. Voragen et al. $(1986,1987)$ have also reported the existence of a highly acetylated pectin fraction isolated from enzymatically digested apples by ultrafiltration.

\subsection{Chromatography}

In ion-exchange chromatography the pectins with lower degrees of methylation eluted as expected with higher salt concentrations (van Deventer-Schriemer \& Pilnik, 1976). SSP alone showed a different behaviour: its ion-exchange chromatography pattern is similar to those obtained with a blockwise repartition of the free carboxyl groups (Anger 
\& Dongowski, 1984). Recoveries were complete except for OHSP, CCSP and CSP: a fraction of the pectic material, probably an almost pure pectate, could not be eluted. Even in these cases, the recoveries were around $100 \%$ for the neutral sugars, which clearly exhibited a different behavior than the galacturonic acid residues in those fractions from alkaline extractions.

Though the pectin extracts often seemed homogeneous in ionexchange chromatography, they are highly polydisperse as shown from their gel-filtration patterns. The mHDP peaks shift to higher $K_{\mathrm{av}}$ in the consecutive extractions. This reflects an increased degradation of the pectin, which is due to the increasingly severe conditions used for the extraction. It is necessary to cut the rhamnogalacturonic backbone into smaller pieces to free the more enmeshed parts of the pectin molecules. OHSP, CCSP and CSP behave similarly in gel-filtration, giving two fractions: they show peaks at high $K_{\mathrm{av}}\left(K_{\mathrm{av}} \sim 0 \cdot 7\right)$ that correspond to material with a molecular weight (for pectins) between $100000\left(K_{\mathrm{av}}=0.6\right)$ and $64000\left(K_{\mathrm{av}}=0 \cdot 7\right)$. The amounts and compositions of these peaks corresponded to the fractions that stayed on the ion-exchange column. At low $K_{\mathrm{av}}$, fractions rich in neutral sugars are present. These subfractions probably correspond to the material that can be detached from the DEAE Sepharose gel and represent 'hairy' regions.

\section{CONCLUSIONS}

CyDTA very efficiently extracted pectin from apple AIS (45\% of the uronides present). Dilute alkalis proved to be the most effective to extract the remaining pectin. However some pectic material could not be extracted under the conditions used.

The fractions obtained with the different extraction conditions had very different neutral sugars/uronic acid ratios, but the relative proportions of the neutral sugars were fairly stable.

The cell wall material and some of the fractions had a high acetyl content. Though it is not certain that the uronides are the only site of attachment of the acetyl groups, it is known that the hairy fragments of apple pectin can have a high degree of acetylation.

The pectin extracted by the alkalis did not have the characteristics reported by De Vries et al. (1981). It notably has a high neutral sugar content accompanied by a high galactose/arabinose ratio. This pectin shows two distinct fractions, one rich in neutral sugars with a high molecular weight, and an almost pure pectate with a lower molecular weight.

There was no evidence of phenolic interlinkages, in contrast to the data reported by Selvendran with cider apples (Selvendran, 1985). 
The conditions used for chemical extractions resulted in some degradation. No studies of the methylation or acetylation are possible after alkaline extractions. The most promising approach is the use of highly purified cell wall degrading enzymes both to characterize further these fractions and to extract pectins.

\section{ACKNOWLEDGEMENTS}

The authors gratefully acknowledge the help of H. A. Schols for useful discussion and of Dr Cheraghi-Sefabad for correcting the English.

\section{REFERENCES}

Ahmed, A. \& Labavitch, J. M. (1977). J. Food Biochem., 1, 361.

Anger, H. \& Dongowski, G. (1984). Die Nahrung, 28, 199.

Aspinall, G. O. \& Fanous, H. K. (1984). Carbohydr. Polym., 4, 193.

Barbier, M. \& Thibault, J. F. (1982). Phytochemistry, 21, 111.

Barrett, A. J. \& Northcote, D. H. (1965). Biochem. J., 94, 617.

Blumenkrantz, N. \& Asboe-Hansen, G. (1973). Anal. Biochem., 54, 484.

De Vries, J. A. (1983). Ph.D. Thesis, Agricultural University, Wageningen, The Nederlands.

De Vries, J. A., Voragen, A. G. J., Rombouts, F. M. \& Pilnik, W. (1981). Carbohydr. Polym., 1, 117.

De Vries, J. A., Rombouts, F. M., Voragen, A. G. J. \& Pilnik, W. (1982). Carbohydr. Polym., 2, 25.

De Vries, J. A., Rombouts, F. M., Voragen, A. G. J. \& Pilnik, W. (1983a). Carbohydr. Polym., 3, 245.

De Vries, J. A., Uijl den C. H., Voragen, A. G. J., Rombouts, F. M. \& Pilnik, W. (1983b). Carbohydr. Polym., 3, 193.

De Vries, J. A., Rombouts, F. M., Voragen, A. G. J. \& Pilnik, W. (1984). Carbohydr. Polym., 4, 89.

Dubois, G., Gilles, K. A., Hamilton, J. R., Rebers, P. A. \& Smith, F. (1956). Anal. Chem., 28, 350 .

Gorin, G., Bonisolli, F., Heidema, F. T., Klop, W. \& Williams, A. A. (1978). Z. Lebensm. Unters. -Forsch., 166, 157.

Hoebler, C., Barry, J. L., David, A. \& Delort-Laval, J. (1989). J. Agric. Food Chem., 37, 360 .

Jarvis, M. C., Hall, H. A., Threlfall, D. R. \& Friend, J. (1981). Planta, 152, 93.

Jarvis, M. C. (1982). Planta, 154, 344.

Kertesz, Z. I.(1951). The Pectic Substances, Interscience, New York.

Knee, M. (1973a). Phytochemistry, 12, 637.

Knee, M. (1973b). Phytochemistry, 12, 1543.

Knee, M., Fielding, A. H., Archer, S. H. \& Laborde, F. (1975). Phytochemistry, $14,2213$.

Knee, M. (1978a). Phytochemistry, 17, 1257. 
Knee, M. (1978b). Phytochemistry, 17, 1261.

Massiot, P., Rouau, X. \& Thibault, J. F. (1988). Carbohydr. Res., 172, 229.

Pilnik, W. \& Voragen, A. G. J. (1970). In The biochemistry of fruits and their products, Vol. 1, ed. A. C. Hulme, Academic Press, New-York, pp. 57-87.

Redgwell, R. J. \& Selvendran, R. R. (1986). Carbohydr. Res., 157, 183.

Rombouts, F. M. \& Thibault, J. M. (1986). Carbohydr. Res., 154, 177.

Roozen, J. P. \& Ouwehand, R. (1978). Voedingsmiddelentechnologie, 11, 23.

Rouau, X. \& Thibault, J. M. (1984). Carbohydr. Polym., 4, 111.

Saulnier, L. \& Thibault, J. M. (1987). Carbohydr. Polym., 7, 329.

Selvendran, R. R. (1985). J. Cell. Sci. Suppl., 2, 51.

Selvendran, R. R., Davies, A. M. C. \& Tidder, E. (1975). Phytochemistry, 14, 2169.

Selvendran, R. R. \& O'Neill, M. A. (1987). In Methods of Biochemical Analysis, vol. 32, ed. D. Glick, J. Wiley \& Sons, New York, pp. 25-153.

Selvendran, R. R., Stevens, B. J. H. \& O'Neill, M. A. (1985). In Biochemistry of Plant Cell Walls, SEB Seminar Series vol. 28, eds. C. T. Brett \& J. R. Hillman, Cambridge University Press, Cambridge, pp. 39-78.

Sihila, H. A. I. (1985). PhD Thesis, Agricultural University, Wageningen, The Netherlands.

Souty, M., Thibault, J. F., Navarro-Garcia, G., Lopez-Roca, J. M. \& Breuils, L. (1981). Sci. Alim., 1, 67.

Stevens, B. J. H. \& Selvendran, R. R. (1984). Carbohydr. Res., 135, 155.

Thibault, J. F. (1979). Lebensm. Wiss. Technol., 12, 247.

Tollier, M. T. \& Robin, J. P. (1979). Ann. Technol. Agric., 28, 1.

Updegraff, D. M. (1969). Anal. Biochem., 32, 420.

Van Deventer-Schriemer, W. H. \& Pilnik, W. (1976). Lebensm. Wiss. Technol., 9,42 .

Van Deventer-Schriemer, W. H. \& Pilnik, W. (1987). Acta Alimentaria, 16, 143.

Voragen, A. G. J., Heutink, R. \& Pilnik, W. (1980). J. Appl. Biochem., 2, 452.

Voragen, A. G. J., Timmers, J. P. J., Linssen, J. P. H., Schols, H. A. \& Pilnik, W. (1983). Z. Lebensm. Unters. -Forsch., 177, 251.

Voragen, A. G. J., Schols, H. A. \& Pilnik, W. (1986). Food Hydrocolloids, 1, 65.

Voragen, A. G. J., Rombouts, F. M., Searle-van Leeuwen, M. F., Schols, H. A. \& Pilnik, W. (1987). Food Hydrocolloids, 1, 423. 
